\title{
Laboratory evaluation to assess the effectiveness of inhibitive nano-water-based drilling fluids for Zubair shale formation
}

\author{
Mortadha Alsaba ${ }^{1}$ - Abdullah Al Marshad ${ }^{2} \cdot$ Ahmed Abbas $^{3} \cdot$ Talal Abdulkareem $^{1} \cdot$ Abdullah Al-Shammary $^{1}$. \\ Meshal Al-Ajmi ${ }^{1} \cdot$ Emad Kebeish $^{1}$
}

Received: 3 April 2019 / Accepted: 16 July 2019 / Published online: 9 August 2019

(c) The Author(s) 2019

\begin{abstract}
While drilling through shale formations, shale hydration, including shale swelling and dispersion, is frequently reported as the main wellbore instability problems, particularly when conventional drilling fluids (water-based) are used. These problems have many adverse effects on the drilling operations resulting in non-productive time. Nanoparticles have been recently introduced as a unique alternative to improve the performance of water-based drilling fluids for shale applications. This paper presents an experimental evaluation to investigate the effectiveness of an inhibitive nano-water-based drilling fluid in reducing the swelling of Zubair shale formation. Well-preserved core samples, which were retrieved from Zubair formation, were characterized using X-ray diffraction, and X-ray fluoresces to quantify the amount of the swelling minerals. Scanning electron microscopy was used to identify the existence of microfractures within the samples. Three different nano-based drilling fluids containing titanium dioxide $\left(\mathrm{TiO}_{2}\right)$, copper oxide $(\mathrm{CuO})$, and magnesium oxide $(\mathrm{MgO})$ at two different concentrations $(0.5 \%$ and $1.5 \%$ by vol) were evaluated through a set of tests to assess the shale reactivity in the presence of these nano-based fluids. In addition, the effect of these nanoparticles on the rheological and filtration properties was studied. The results showed that the shale samples contain $41.26 \%$ silicon dioxide $\left(\mathrm{SiO}_{2}\right)$ and $22.73 \%$ aluminum oxide $\left(\mathrm{Al}_{2} \mathrm{O}_{3}\right)$, indicating the presence of smectite and illite. Based on the reactivity tests, fluids containing $\mathrm{CuO}$ at $1.5 \%$ by vol outperformed the other fluids in terms of reducing the reactivity, where the expansion rate was reduced by $82.7 \%$ compared to the reference sample submerged in fresh water. In addition, the addition of nanoparticles resulted in reducing the plastic viscosity, increasing both the yield point and gel strength, and reducing the fluid loss under low-pressure low-temperature conditions.
\end{abstract}

Keywords Inhibitive drilling fluid $\cdot$ Nanofluid $\cdot$ Nanoparticles $\cdot$ Shale reactivity $\cdot$ Laboratory investigation

\section{Introduction}

Drilling through shale formations is considered as one of the major challenges worldwide due to the wellbore instability related issues. The Zubair formation in Southern Iraq consists of almost 55\% shale, which results in approximately $70 \%$ of wellbore instabilities while drilling due to the ineffectiveness of the added inhibitors in reducing the shale

Mortadha Alsaba

m.alsaba@ack.edu

1 Petroleum Engineering Department, Australian College of Kuwait, P.O. Box 1411, Safat, 13015 Kuwait City, Kuwait

2 Kuwait Institute for Scientific Research, P.O. Box 24885, Safat, 13109 Kuwait City, Kuwait

3 Iraqi Drilling Company, P.O. Box 941, Al Borjsea, Basra 19312, Iraq reactivity (Abbas et al. 2018a). These instabilities, which include shale swelling, wellbore collapse, pipe sticking, etc., could result in unwanted non-productive time (NPT) that increases the overall drilling cost. The chemical interaction between drilling fluids and shale is one of the factors that could lead to these instabilities (Horsrud et al. 1998; Carminati et al. 2001; Balaban et al. 2015); hence, proper selection and evaluation of the shale inhibitors used in drilling fluid play a major role in mitigating this type of instability due to the chemical and physical complexity of the shale (Van Oort 2003). Understanding the characteristics of the shale such as the mineralogy, structure, and reactivity is crucial for the selection of shale inhibitors.

Oil-based drilling fluids (OBM), including syntheticbased drilling fluids (SBM), are often used to drill through shale section due to their effectiveness in inhibition as a result of the lesser amount of water in their formulation.

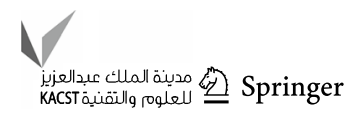


However, OBM is not considered environmentally friendly fluid; therefore, water-based drilling fluids (WBM) are often preferred. Different types of salts including sodium chloride $(\mathrm{NaCl})$, potassium chloride $(\mathrm{KCL})$, and calcium chloride $\left(\mathrm{CaCl}_{2}\right)$ are often used as shale inhibitors. The usage of salts as inhibitors is due to the fact that increasing the concentration of salts in the WBM will result in reducing the ionic exchange process between the shale and water, hence lesser magnitude of shale hydration (Doleschall et al. 1987).

In a recent investigation, Abbas et al. 2018b conducted an experimental investigation to assess the effectiveness of $\mathrm{NaCl}, \mathrm{KCL}$, and a mixture of $\mathrm{KCL}$ and glycol in reducing the reactivity of the Zubair shale. Different tests were conducted to characterize the shale samples first including thin-section analysis, X-ray diffraction analysis (XRD), and scanning electron microscopy (SEM), and then the selected fluids were evaluated using cation exchange capacity (CEC), hot rolling dispersion test, capillary suction time test (CST), and linear swell meter test (LSM). The results showed that the mixture of $7 \% \mathrm{KCl}$ and $3 \%$ glycol outperformed both the $7 \%$ by wt. $\mathrm{KCl}$ brine and the $20 \%$ by wt. $\mathrm{NaCl}$ brine and resulted in a reduction of the swelling rate by approximately $66 \%$.

Nanofluids, which can be simply defined as fluids containing suspended nano-meter sized particles with sizes ranging between 1 and $100 \mathrm{~nm}$, have recently proven their effectiveness for different applications in the oil and gas industry. These applications include improving the rheological properties of drilling fluids (Barry et al. 2015; Ponmani et al. 2016; Al-Zubaidi et al. 2017; Perween et al. 2018; Parizad et al. 2018; Minakov et al. 2018, Alsaba et al. 2018), wellbore strengthening (Nwaoji et al. 2013; Contreras et al. 2014a, b; Kang et al. 2016), cementing (Ahmed et al. 2018; Alkhamis and Imqam 2018; Vipulanandan et al. 2018), stimulation (Singh et al. 2018; Fakoya and Shah 2018), shale stabilization (Sensoy et al. 2009; Akhtarmanesh et al. 2013; Hoxha et al. 2017; Pourkhalil and Nakhaee 2019), and enhanced oil recovery (EOR) (Zargartalebi et al. 2014; Abdullahi et al. 2019; Ding et al. 2018; Suresh et al. 2018; Elshawaf 2018; Almohsin et al. 2018).

In this study, different techniques were used to first characterize the retrieved shale samples in order to quantify the amount of swelling minerals and examine the existence of fractures within the samples. In addition, different shale reactivity tests were conducted to evaluate the effectiveness of nanoparticles in reducing the reactivity of the shale samples using nano-water-based drilling fluid (NWBM). The main objective of this study is to determine the best nanoparticle type and concentration in terms of reducing the shale reactivity, which suggests its applicability in being used as an inhibitive for water-based drilling fluids.

\section{Methodology}

\section{Shale characterization}

Different tests were conducted in this study on well-preserved shale core samples, which were collected from different wells to cover a wide range of the Zubair formation intervals. These tests included X-ray computed tomography (CT), scanning electron microscopy (SEM), X-ray diffraction (XRD), and X-ray fluorescence (XRF). The main objective of running these tests is to characterize the samples in terms of the structure, mineral composition, and the existence of fractures. A detailed description of the above-mentioned tests can be found elsewhere (Abbas et al. 2018b).

\section{Fluid used}

Three different fluids containing nanoparticles at two different concentrations were prepared and used in this study in addition to fresh water as a reference point to evaluate the effect of adding nanoparticles on the shale reactivity. While a simple $7 \%$ bentonite drilling fluid was used as the reference point for evaluating effect of nanoparticles on the rheological properties and filtration characteristics. The nanoparticles evaluated included titanium dioxide $\left(\mathrm{TiO}_{2}\right)$, copper oxide $(\mathrm{CuO})$, and magnesium oxide $(\mathrm{MgO})$ at two different concentrations $(0.5 \%$ and $1.5 \%$ by vol), where the $0.5 \%$ was considered as low concentration and the $1.5 \%$ as a very high concentration of nanoparticles. The composition of the tested fluids is summarized in Table 1.

\section{Shale reactivity}

To evaluate the effect of nanoparticles on the shale reactivity, different tests were conducted in this study. These tests included the cation exchange capacity (CEC), expansion rate (semiquantitative), and a qualitative hardness test. The

Table 1 Composition of the used fluids

\begin{tabular}{llllll}
\hline Fluid type & $\begin{array}{l}\text { Bentonite } \\
(\mathrm{g})\end{array}$ & Water $(\mathrm{ml})$ & $\mathrm{CuO}(\mathrm{g})$ & $\mathrm{TiO}_{2}(\mathrm{~g})$ & $\mathrm{MgO}(\mathrm{g})$ \\
\hline $\begin{array}{l}7 \% \text { benton- } \\
\text { ite }\end{array}$ & 35 & 465 & - & - & - \\
$0.5 \% \mathrm{CuO}$ & 35 & 465 & 2.5 & - & - \\
$1.5 \% \mathrm{CuO}$ & 35 & 465 & 7.5 & - & - \\
$0.5 \% \mathrm{TiO}_{2}$ & 35 & 465 & - & 2.5 & - \\
$1.5 \% \mathrm{TiO}_{2}$ & 35 & 465 & - & 7.5 & - \\
$0.5 \% \mathrm{MgO}^{2}$ & 35 & 465 & - & $\mathrm{x}$ & 2.5 \\
$1.5 \% \mathrm{MgO}$ & 35 & 465 & $\mathrm{x}$ & $\mathrm{x}$ & 7.5 \\
\hline
\end{tabular}




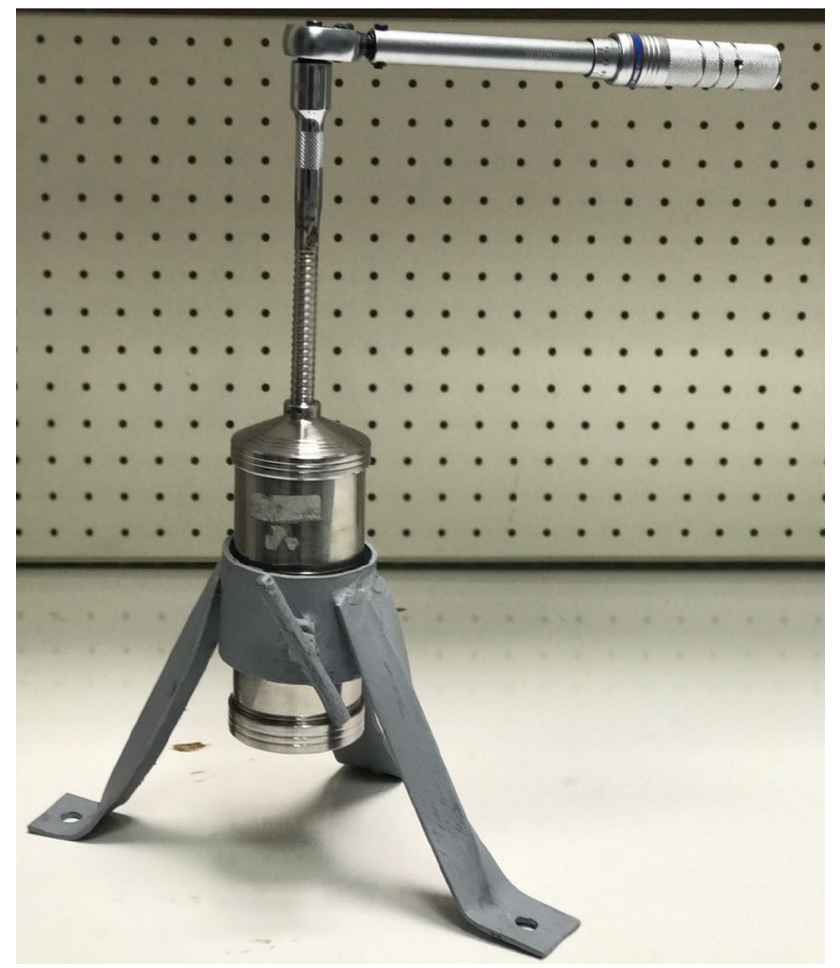

Fig. 1 Qualitative hardness test apparatus

CEC test was conducted according to the API-RP-13I (API 2004).

The expansion rate test was conducted by measuring the weight of the dry sample first and then submerging the shale sample in a container containing the test fluid and leaving it for $24 \mathrm{~h}$. After $24 \mathrm{~h}$, the wet sample weight is then measured and recorded and the percentage of the expansion rate is then calculated as follows:

Fig. 2 CT scan images for full core $(1 \mathrm{~m})$. (after Abbas et al. 2018b)
$\%$ Expansion rate $=\frac{\text { Wet sample weight }- \text { Dry sample weight }}{\text { Dry weight }} \times 100$

This test is semiquantitative since it will give an indication of how much water is being absorbed when comparing the wet to dray sample weight. If the fluid used is inhibitive, then the amount of water absorbed will decrease, resulting in reducing the expansion rate. The results obtained from this test are compared to a reference sample, which contains fresh water only.

The qualitative hardness tests were conducted using an in-house-made simple apparatus (Fig. 1), which was used to measure the required force to break the core sample after being exposed to the different fluids. This test can also give a qualitative indication on the shale reactivity due to the fact that the shale samples will become softer due to swelling. The shale samples were exposed to forces ranging between 5 and $25 \mathrm{Nm}$ using a torque wrench which is connected to a piston that is placed on the top of shale samples to compress them. The force is applied until the sample breaks, and the amount of force required to break the sample is recorded.

\section{Results and discussion}

\section{Shale characterization}

The CT scan images for the full core section demonstrated the presence of microfractures as can be seen in Fig. 2, where the green and yellow arrows point to the induced fracture and natural open fractures, respectively.

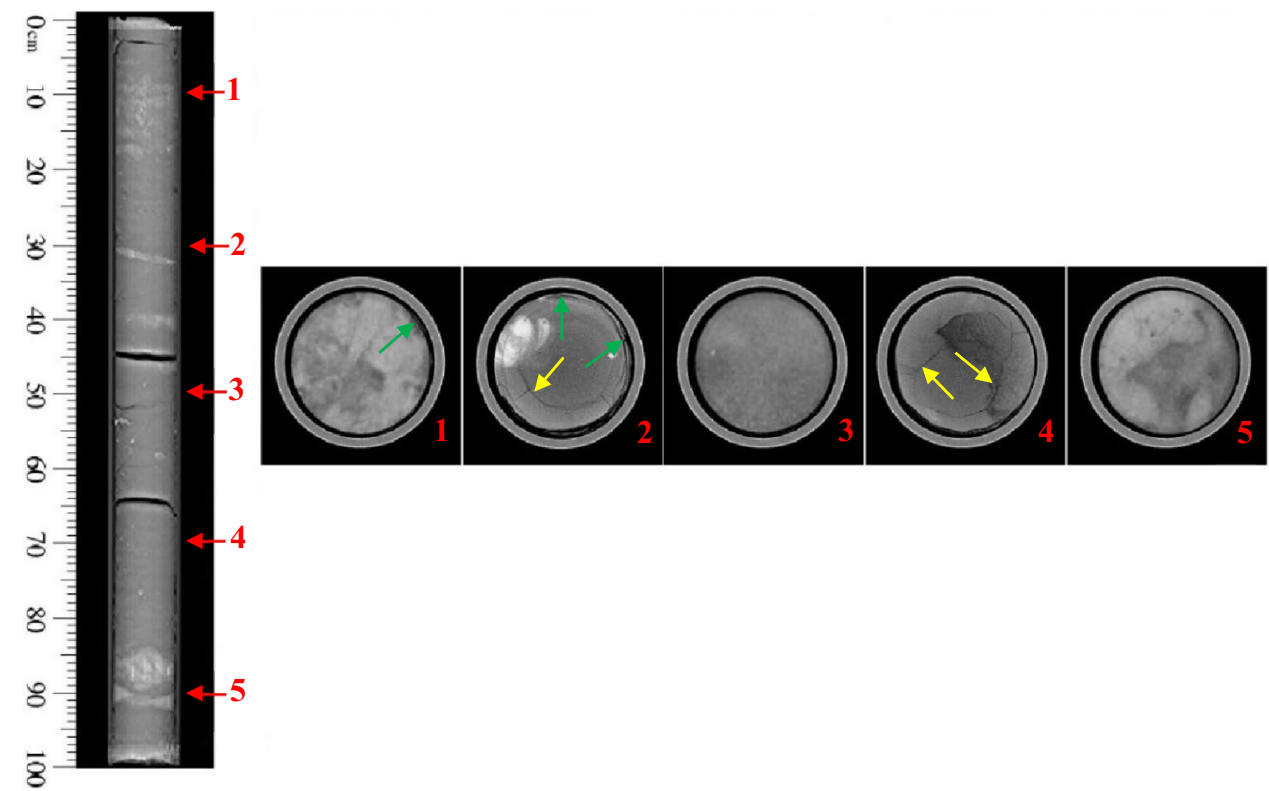




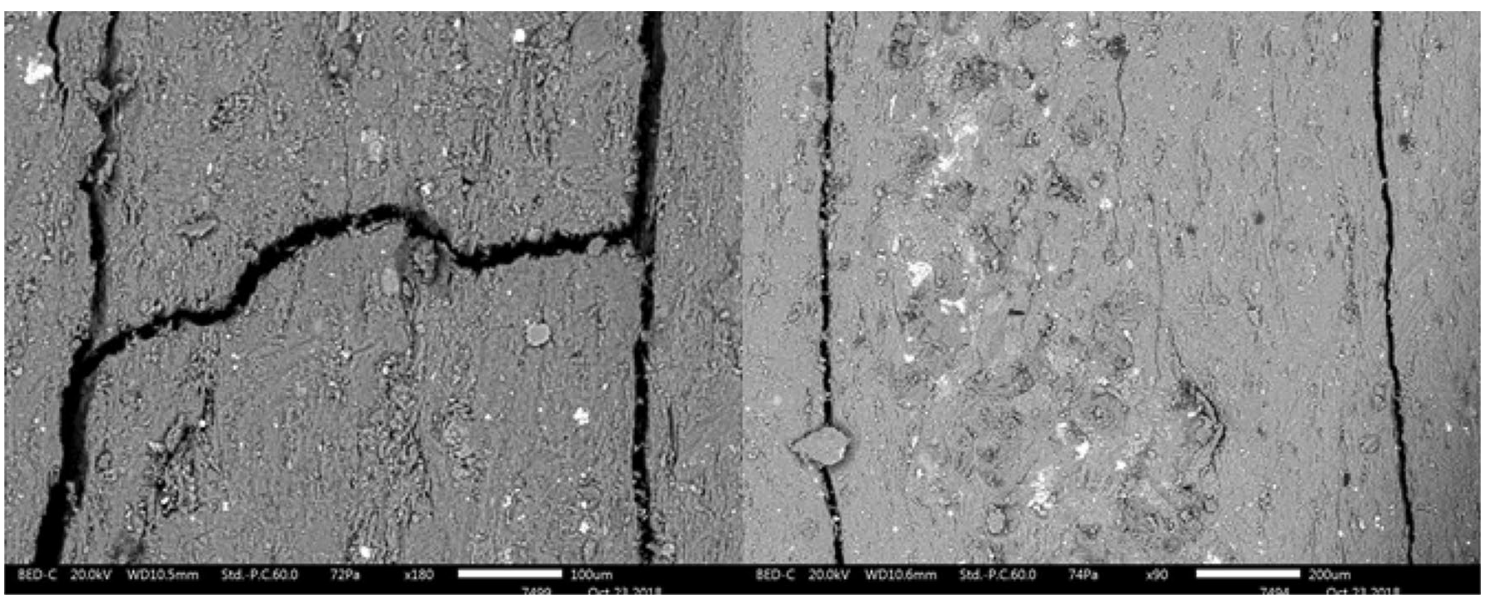

Fig. 3 Presence of microfractures

Table 2 XRF analysis results

\begin{tabular}{lll}
\hline Element & Formula & Concentration \\
\hline $\mathrm{Na}$ & $\mathrm{Na}_{2} \mathrm{O}$ & $0.512 \%$ \\
$\mathrm{Mg}$ & $\mathrm{MgO}$ & $1.485 \%$ \\
$\mathrm{Al}$ & $\mathrm{Al}_{2} \mathrm{O}_{3}$ & $22.73 \%$ \\
$\mathrm{Si}$ & $\mathrm{SiO}_{2}$ & $41.256 \%$ \\
$\mathrm{~S}$ & $\mathrm{SO}_{3}$ & $1.191 \%$ \\
$\mathrm{~K}$ & $\mathrm{~K}_{2} \mathrm{O}$ & $2.27 \%$ \\
$\mathrm{Ca}$ & $\mathrm{CaO}$ & $3.712 \%$ \\
$\mathrm{Ti}$ & $\mathrm{Ti}$ & $0.859 \%$ \\
$\mathrm{Fe}$ & $\mathrm{Fe}$ & $\mathrm{O}_{3}$ \\
$\mathrm{Rb}$ & $\mathrm{Rb}$ & $8.353 \%$ \\
$\mathrm{Sr}$ & $\mathrm{Sr}$ & $92.3 \mathrm{ppm}$ \\
$\mathrm{Zr}$ & $\mathrm{Zr}$ & $233.2 \mathrm{ppm}$ \\
\hline
\end{tabular}

The SEM images (Fig. 3) indicate the presence of microfractures. Overall, the core samples exhibited microfractures ranging between 0.4 and $3 \mu \mathrm{m}(400-3000 \mathrm{~nm})$.
The mineral composition of the shale sample obtained from XRF analysis is tabulated in Table 2, which shows that the sample consists mainly of $41.26 \%$ silicon dioxide $\left(\mathrm{SiO}_{2}\right)$ and $22.73 \%$ aluminum oxide $\left(\mathrm{Al}_{2} \mathrm{O}_{3}\right)$, indicating the presence of smectite and illite, where the smectite has higher tendency to swelling when in contact with water (Aghamelu and Okogbue 2015).

Figure 4 shows the obtained results from the XRD analysis along with the list of phases within the sample, which indicates the nature and identification of the individual phases within the shale sample. However, the identification of these phases depends on the crystalline nature of the core and can be distinguished by using the $2 \Theta \chi$ values from Brag's equation. The amorphous material is not expected to be identified with the XRD even if it is partially crystalized. Details about the different shale sample phases are tabulated in Table 3.
Fig. 4 XRD analysis of the shale sample

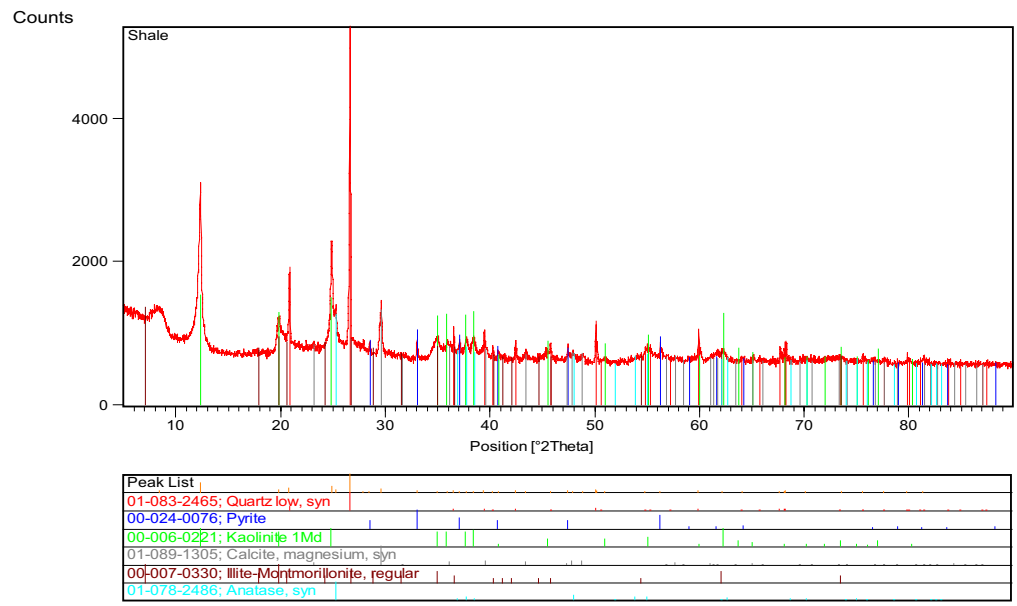


Table 3 Tabulated XRD results

\begin{tabular}{lll}
\hline Ref. code & Compound name & Chemical formula \\
\hline $01-083-2465$ & Quartz low & $\mathrm{SiO}_{2}$ \\
$00-024-0076$ & Pyrite & $\mathrm{FeS}_{2}$ \\
00-006-0221 & Kaolinite & $\mathrm{Al}_{2} \mathrm{Si}_{2} \mathrm{O}_{5}(\mathrm{OH})_{4}$ \\
$01-089-1305$ & Calcite, magnesium & $\left(\mathrm{Mg}_{0.06} \mathrm{Ca}_{0.94}\right)\left(\mathrm{CO}_{3}\right)$ \\
00-007-0330 & Illite-smectite & $\mathrm{K}_{-} \mathrm{Al}_{4}(\mathrm{SiAl})_{8} \mathrm{O}_{20}(\mathrm{OH})_{4} \times \mathrm{H}_{2} \mathrm{O}$ \\
01-078-2486 & Anatase & $\mathrm{TiO}_{2}$ \\
\hline
\end{tabular}

Table 4 The result of CEC test

\begin{tabular}{lllll}
\hline Fluid type & $\begin{array}{l}\text { NP } \\
\text { concentra- } \\
\text { tion\% }\end{array}$ & $\begin{array}{l}\text { Amount of methyl- } \\
\text { ene blue used (ml) }\end{array}$ & CEC & $\begin{array}{l}\text { Reactive clay } \\
\text { content }(\mathrm{lb} / \mathrm{bbl})\end{array}$ \\
\hline Water & - & 0.5 & 0.5 & 2.5 \\
$\mathrm{CuO}$ & 0.5 & 0.4 & 0.4 & 2 \\
$\mathrm{CuO}$ & 1.5 & 0.2 & 0.2 & 1 \\
$\mathrm{TiO}_{2}$ & 0.5 & 0.5 & 0.5 & 2 \\
$\mathrm{TiO}_{2}$ & 1.5 & 0.4 & 0.4 & 2.5 \\
$\mathrm{MgO}_{\mathrm{MgO}}$ & 0.5 & 0.5 & 0.5 & 2 \\
$\mathrm{MgO}$ & 1.5 & 0.4 & 0.4 & 2.5 \\
\hline
\end{tabular}

\section{Shale reactivity}

\section{Cation exchange capacity (CEC)}

Table 4 summarizes the results obtained for the cation exchange capacity test (CEC) conducted after exposing the shale samples to the above-mentioned fluids.

Based on the results, it can be seen that the $\mathrm{CuO}$ at $1.5 \%$ by vol concentration resulted in reducing the amount of reactive clay by $60 \%$ compared to the reference point. This is an indication that the $\mathrm{CuO}$ has severely reduced the reactivity of the clay content of the shale when compared to the other fluids. On the one hand, $\mathrm{CuO}, \mathrm{MgO}$, and $\mathrm{TiO}_{2}$ at low concentration $(0.5 \%$ by vol) showed a reduction of approximately $20 \%$ compared to the reference point; however, when the concentration was increased using $\mathrm{MgO}$ and $\mathrm{TiO}_{2}$, no effect in reducing the reactivity was observed. It is important to mention that this analysis is qualitative due to the uncertainties with respect to the endpoint of the test. Figure 5 shows graphically the obtained results of the reactive clay content.

\section{Expansion rate}

The results of this simple approach showed the expansion rate of the shale sample, as a function of weight increase, using different types of nano-based fluids with two different concentrations $(0.5 \%$ and $1.5 \%)$ in order to assess the effect

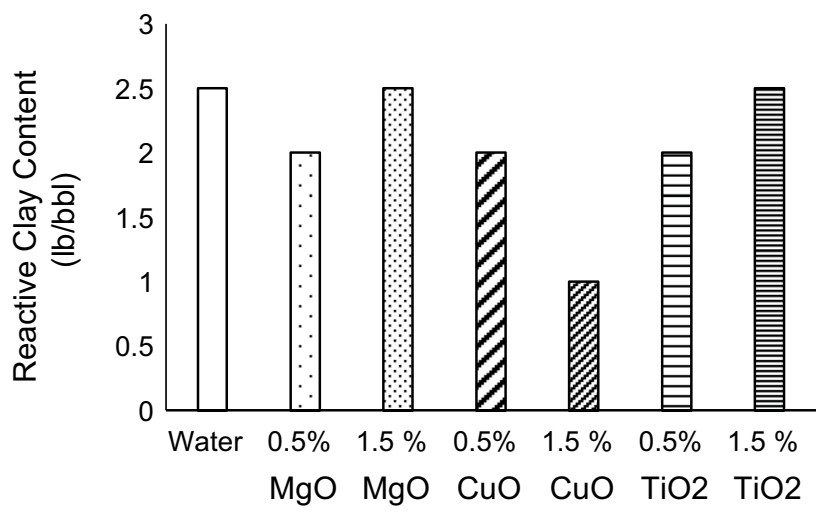

Fig. 5 Reactive clay content (lb/bbl) after being exposed to different fluids

Table 5 Results of expansion by weight

\begin{tabular}{lllll}
\hline Fluid used & $\begin{array}{l}\text { NP Concn. } \\
\text { \% by vol }\end{array}$ & $\begin{array}{l}\text { Dry shale } \\
\text { sample wt } \\
(\mathrm{g})\end{array}$ & $\begin{array}{l}\text { Wet shale } \\
\text { sample wt } \\
\text { after 48 } \mathrm{h}(\mathrm{g})\end{array}$ & $\begin{array}{l}\text { \% increase } \\
\text { in wt }\end{array}$ \\
\hline Water & 0 & 1.5 & 1.6 & 6.67 \\
$\mathrm{CuO}$ & 0.5 & 2.21 & 2.34 & 5.88 \\
$\mathrm{CuO}$ & 1.5 & 2.6 & 2.63 & 1.15 \\
$\mathrm{TiO}_{2}$ & 0.5 & 2.29 & 2.36 & 3.05 \\
$\mathrm{TiO}_{2}$ & 1.5 & 1.5 & 1.58 & 5.33 \\
$\mathrm{MgO}$ & 0.5 & 2.97 & 3.18 & 7.07 \\
$\mathrm{MgO}$ & 1.5 & 2.6 & 2.71 & 4.23 \\
\hline
\end{tabular}

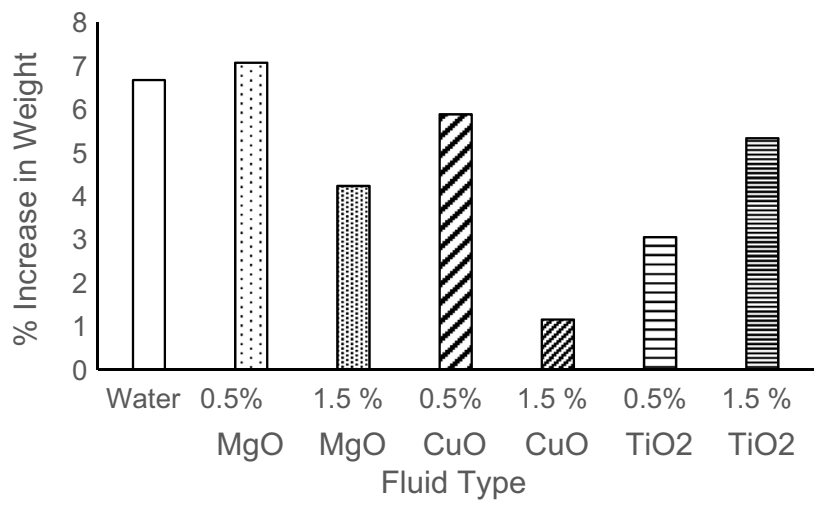

Fig. $6 \%$ increase in wt for the different fluids

of the nanoparticles on reducing the absorption of water by the shale sample. Table 5 shows the results of all the tests conducted.

The results clearly demonstrate the effect of nanoparticles on reducing the amount of water absorbed by the shale samples (Fig. 6). Based on the results, it can be clearly observed that the $\mathrm{CuO}$ at $1.5 \%$ by vol concentration outperformed all the nanoparticles at high and low 
concentrations compared to the reference point, which contains fresh water only, with a reduction in the \% increase in weight by approximately $83 \%$. The $\mathrm{TiO}_{2}$ also exhibited a lower \% of increase in the sample weight at a concentration of $0.5 \%$ by vol suggesting a reduction by $54 \%$ compared to the fresh water. However, the $\mathrm{MgO}$ at $0.5 \%$ by vol showed a negative effect where the $\%$ has increased by approximately $6 \%$. The obtained results from this test are in agreement with the finding from the reactive clay content test.

\section{Qualitative hardness test}

Previous studies have shown that swelling will affect the shale strength (Lal 1999; Shi et al. 2018; Beg et al. 2018). It is believed that the more adsorption of the water by the shale, the weaker the sample it gets. The qualitative hardness test results shown in Table 6 have confirmed the previous tests result. The results clearly show that the sample exposed to fresh water was the weakest sample, where it was partially broken at $9 \mathrm{Nm}$ compared to all other samples, while the sample exposed to $1.5 \%$ by vol $\mathrm{CuO}$ didn't break at the maximum applied force, which is in agreement with the previous tests. The sample exposed to $0.5 \%$ by vol $\mathrm{CuO}$ broke at the minimum force applied, which is believed to be due to an experimental error while conducting the test, and thus this result is not representative.

\section{SEM/EDX images}

Based on the obtained results from the different tests above, the sample containing $\mathrm{CuO}$ at $1.5 \%$ by vol showed the best performance in terms of reducing the shale reactivity; therefore, it was decided to take a closer look at the shale sample using the scanning electron microscopy/energy-dispersive $\mathrm{X}$-ray spectroscopy (SEM/EDS) in order to observe the shale sample surface before and after being exposed to the nanofluid.

Figure 7 shows SEM images, which were taken prior to submerging the shale samples into the select fluid. Figure 8 shows the same sample after being exposed to the fluid containing $\mathrm{CuO}$ at $1.5 \%$ by vol which clearly shows the presence of the nanoparticles (lighter color) on the sample surface.

Figure 9 shows the EDS images of the sample (a) before and (b) after being exposed to the selected nanofluid in order to clearly observe how the $\mathrm{CuO}$ nanoparticles were covering

Table 6 Bulk hardness result

\begin{tabular}{lllllll}
\hline Sample & Concentration & \multicolumn{5}{l}{ Force applied } \\
\cline { 3 - 7 } & & $5 \mathrm{Nm}$ & $9 \mathrm{Nm}$ & $13 \mathrm{Nm}$ & $21 \mathrm{Nm}$ & $25 \mathrm{Nm}$ \\
\hline Water & - & No & Partially & Broken & - & - \\
$\mathrm{CuO}$ & 0.5 & Broken & - & - & - & - \\
$\mathrm{CuO}$ & 1.5 & No & No & No & No & No \\
$\mathrm{TiO}_{2}$ & 0.5 & No & No & No & Broken & - \\
$\mathrm{TiO}_{2}$ & 1.5 & No & No & No & No & Broken \\
$\mathrm{MgO}$ & 0.5 & No & No & Broken & - & - \\
$\mathrm{MgO}$ & 1.5 & No & No & No & Broken & - \\
\hline
\end{tabular}
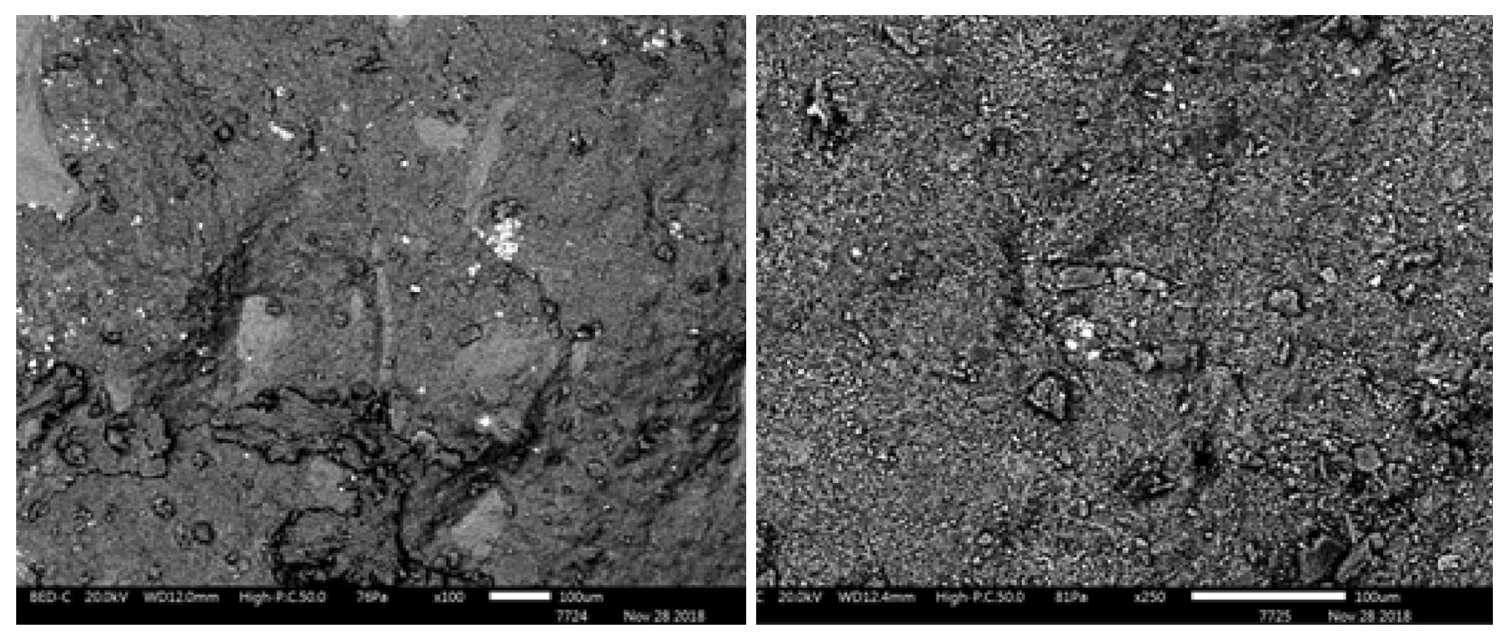

Fig. 7 SEM image of the shale sample before exposer to fluid

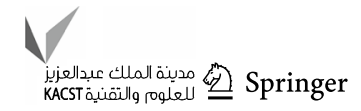



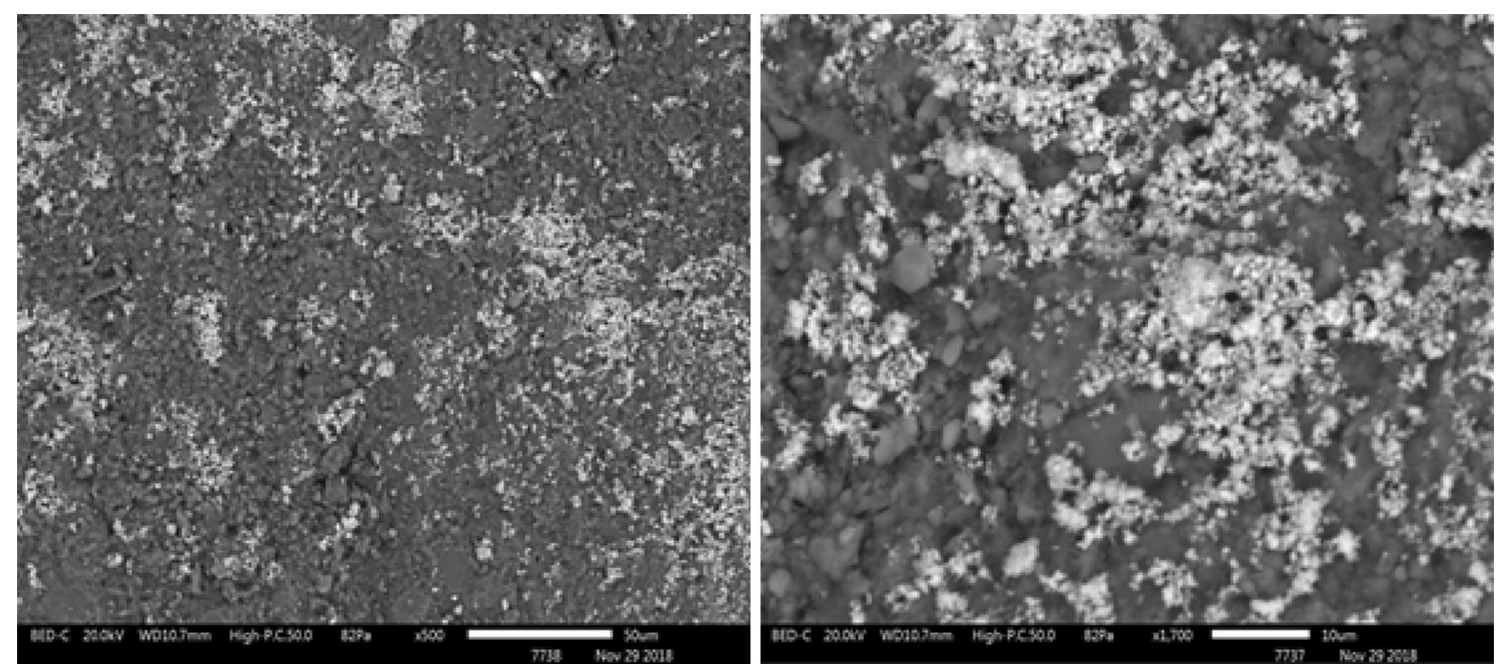

Fig. 8 SEM image of the shale sample after exposer to fluid

Si Ka1

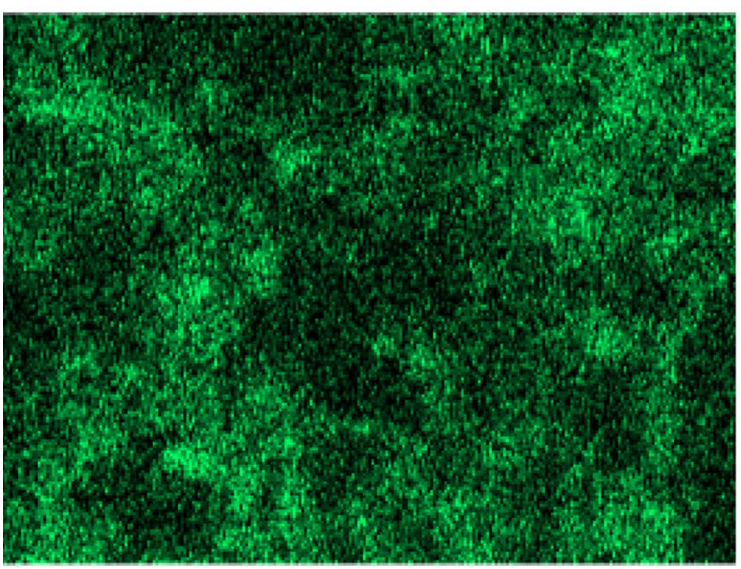

$25 \mu \mathrm{m}$

\section{Cu K $\alpha 1$}

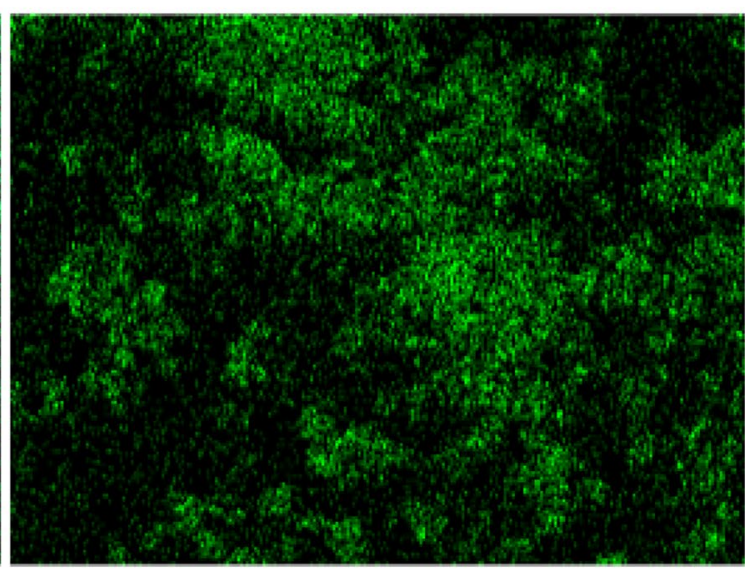

$25 \mu \mathrm{m}$

Fig. 9 EDS image showing the sample surface before (left) and after (right) being exposed to CuO nanofluid

the presence of $\mathrm{SiO}_{2}$. It can be clearly seen in terms of color contrast between the two images that the $\mathrm{Cu}$ covered the presence of $\mathrm{Si}$, which can explain the reduction in the shale reactivity. This is believed to be due to plugging the pore spaces as found previously by Hoxha et al. 2017, which resulted in reducing the water invasion into the shale and hence reducing the reactivity of the shale.

\section{Effect of nanoparticles on the rheological properties and filtration characteristics}

A summary of results for the tests conducted to evaluate the effect of nanoparticles on the rheological and filtration characteristics is summarized in Table 7.
Overall, it can be clearly observed that the added nanoparticles resulted in affecting the rheological properties in a favorable way. On the one hand, the plastic viscosity was reduced for all the blends except for the nanofluids containing $\mathrm{TiO}_{2}$; on the other hand, both yield point and $10 \mathrm{~s}$ gel strength increased for all blends containing nanoparticles. The nanoparticles showed a minor effect on the $\mathrm{pH}$ as shown in Table 7. For the filtration characteristics, a reduction in the fluid loss was observed for both blends containing $\mathrm{TiO}_{2}$ and $\mathrm{CuO}$. However, for blends containing $\mathrm{MgO}$, a negative effect was observed on the filtration characteristics, where the fluid loss increased dramatically compared to the reference point ( $7 \%$ bentonite).

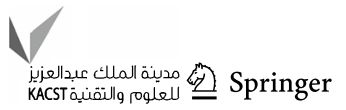


Table 7 Summary of the test results

\begin{tabular}{|c|c|c|c|c|c|c|c|c|}
\hline Blends\# & Ө6 RPM & O3 RPM & Gel $\left(\mathrm{lb} / 100 \mathrm{ft}^{2}\right)$ & $\mathrm{PV}(\mathrm{cP})$ & $\mathrm{YP}\left(\mathrm{lb} / 100 \mathrm{ft}^{2}\right)$ & $\mathrm{pH}$ & $\begin{array}{l}\text { Fluid loss } \\
(\mathrm{ml} / 30 \mathrm{ml})\end{array}$ & $\begin{array}{l}\text { Filter cake } \\
\text { thickness } \\
\text { (in.) }\end{array}$ \\
\hline $7 \%$ bentonite & 20 & 20 & 21 & 4 & 19 & 9.26 & 25 & 0.083 \\
\hline $0.5 \% \mathrm{CuO}$ & 35 & 35 & 33 & 2 & 35 & 9.2 & 22 & 0.085 \\
\hline $1.5 \% \mathrm{CuO}$ & 37 & 37 & 37 & 2 & 37 & 9.17 & 22.5 & 0.1 \\
\hline $0.5 \% \mathrm{TiO}_{2}$ & 23 & 20 & 32 & 5 & 27 & 8.7 & 19 & 0.13 \\
\hline $1.5 \% \mathrm{TiO}_{2}$ & 32 & 29 & 35 & 7 & 35 & 8.9 & 19.5 & 0.13 \\
\hline $0.5 \% \mathrm{MgO}$ & 48 & 38 & 35 & 3 & 63 & 10.7 & 45 & 0.18 \\
\hline $1.5 \% \mathrm{MgO}$ & 51 & 43 & 34 & 2 & 62 & 10.7 & 54 & 0.18 \\
\hline
\end{tabular}
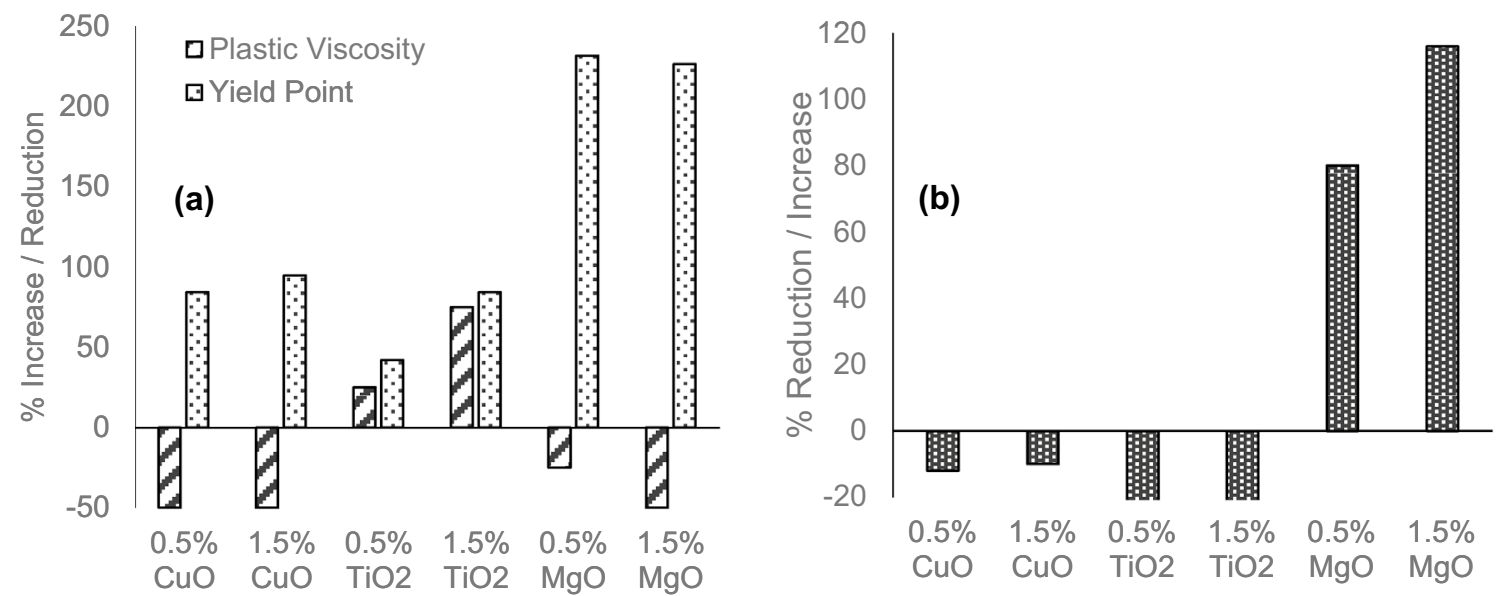

Fig. 10 Effect of nanoparticles on a plastic viscosity and yield point, and $\mathbf{b}$ fluid loss

Figure 10 shows a comparison for all nanofluids used along with the $\%$ increase/reduction in plastic viscosity, yield point (Fig. 10a), and fluid loss (Fig. 10b), when compared to the reference drilling fluid (7\% Bentonite).

It can be clearly observed that the reduction in plastic viscosity ranged between 25 and $50 \%$ for blends containing $\mathrm{CuO}$ and $\mathrm{MgO}$ (Fig. 10a), while the increase was reflected for $\mathrm{TiO}_{2}$. The yield point $\%$ increases ranged between 40 and $200 \%$, where the highest increase was observed when adding $\mathrm{MgO}$ nanoparticles. The highest reduction in fluid loss was achieved when adding $\mathrm{TiO}_{2}$, which was up to $24 \%$. However, a negative increase in the fluid loss value up to $116 \%$ was observed when using $\mathrm{MgO}$. The effect of increasing the concentration of nanoparticles on the magnitude of enhancement was not significant, suggesting that lower concentrations of nanoparticles are preferred.

\section{Conclusions}

The laboratory evaluation presented in this paper demonstrated clearly the effectiveness of different nanoparticles on the shale reactivity as well as the rheological and filtration properties of the drilling fluid. Based on the results and analysis conducted, the following can be concluded:

- The mineral characterization of the shale samples using XRD and XRF showed that this type of shale consists of $41.256 \%$ of $\mathrm{SiO}_{2}$ and $22.73 \%$ of $\mathrm{Al}_{2} \mathrm{O}_{3}$, which indicates the presence of smectite and illite.

- The SEM images showed an average microfracture width of $437.5 \mathrm{~nm}$.

- Based on the different reactivity tests conducted, fluids containing $\mathrm{CuO}$ nanoparticles at $1.5 \%$ concentration by vol resulted in the best inhibition.

- The addition of $\mathrm{CuO}$ at $1.5 \%$ by vol resulted in reducing the water absorption by approximately $83 \%$ compared 
to the reference point, while the addition of $\mathrm{TiO}_{2}$ at $0.5 \%$ by vol resulted in a reduction up to $54 \%$.

- The exposer of the shale samples to the fluid containing $\mathrm{CuO}$ at $1.5 \%$ by vol resulted in reducing the amount of reactive clay by $60 \%$.

- The SEM/EDS analysis of the shale samples before and after being exposed to the fluid containing $\mathrm{CuO}$ at $1.5 \%$ by vol showed clearly how the $\mathrm{Cu}$ covered the presence of $\mathrm{Si}$, which is in agreement with the reactivity test results.

- Based on the results, both $\mathrm{TiO}_{2}$ and $\mathrm{CuO}$ can be considered as good inhibitors that have the capability of minimizing the shale reactivity.

- Based on the effect of nanoparticles on both rheological and filtration properties, both $\mathrm{TiO}_{2}$ and $\mathrm{CuO}$ did not negatively affect the drilling fluid, where a reduction in the fluid loss by $12 \%$ and $24 \%$ was observed for both $\mathrm{CuO}$ and $\mathrm{TiO}_{2}$ at low concentration $(0.5 \%$ by vol), respectively.

- In addition, an acceptable increase in the yield point (up to $95 \%$ ) was achieved for both $\mathrm{CuO}$ and $\mathrm{TiO}_{2}$ at low concentration $(0.5 \%$ by vol).

Acknowledgements The authors would like to acknowledge the Australian College of Kuwait for their continuous help and support. Special thanks to Basrah Oil Company in Iraq for their help in providing the core samples as well as their permission to publish the results. Many thanks to the Kuwait Institute for Scientific Research (KISR) for providing the facilities and guidance to do this work. Special thanks to Eng. Hussain Jam for his help in the laboratory.

Open Access This article is distributed under the terms of the Creative Commons Attribution 4.0 International License (http://creativeco mmons.org/licenses/by/4.0/), which permits unrestricted use, distribution, and reproduction in any medium, provided you give appropriate credit to the original author(s) and the source, provide a link to the Creative Commons license, and indicate if changes were made.

\section{References}

Abbas A, Flori R, Al-Anssari A, Alsaba M (2018) Laboratory analysis to assess shale stability for the Zubair Formation, Southern Iraq. J Nat Gas Sci Eng 56:315-323. https://doi.org/10.1016/j.jngse .2018.05.041

Abdullahi M, Rajaei K, Junin R, Ali B (2019) Appraising the impact of metal-oxide nanoparticles on rheological properties of HPAM in different electrolyte solutions for enhanced oil recovery. J Pet Sci Eng 172:1057-1068. https://doi.org/10.1016/j.petrol.2018.09.013

Aghamelu O, Okogbue C (2015) Characterization of some clays from Nigeria for their use in drilling mud. Appl Clay Sci 116-117:158166. https://doi.org/10.1016/j.clay.2015.08.025

Ahmed S, Ezeakacha P, Salehi S (2018) Improvement in cement sealing properties and integrity using conductive carbon nano materials: from strength to thickening time. In: SPE annual technical conference and exhibition, Dallas, TX, USA. 24-26 Sept. https:// doi.org/10.2118/191709-MS
Akhtarmanesh S, Ameri Shahrabi M, Atashnezhad A (2013) Improvement of wellbore stability in shale using nanoparticles. J Pet Sci Eng 112:290-295. https://doi.org/10.1016/j.petrol.2013.11.017

Alkhamis M, Imqam A (2018) New cement formulations utilizing graphene nano platelets to improve cement properties and long-term reliability in oil wells. In: SPE Kingdom of Saudi Arabia annual technical symposium and exhibition, Dammam, Saudi Arabia. 23-26 April. https://doi.org/10.2118/192342-MS

Almohsin A, Alsharaeh E, Fathima A, Bataweel M (2018) A novel polymer nanocomposite graphene based gel for high temperature water shutoff applications. In: SPE Kingdom of Saudi Arabia annual technical symposium and exhibition, Dammam, Saudi Arabia. 23-26 April. https://doi.org/10.2118/192358-MS

Abbas K, Al-Asadi M, Alsaba, M, Flori R, Alhussainy S (2018a) Development of a geomechanical model for drilling deviated wells through the Zubair formation in Southern Iraq. In: SPE/ IADC Middle east drilling technology conference and exhibition, 29-31 Jan, Abu Dhabi, UAE. https://doi.org/10.2118/189306-MS

Alsaba M, Al Fadhli A, Marafi A, Hussain A, Bander F, Al Dushaishi M (2018) Application of nanoparticles in improving rheological properties of water based drilling fluids. In: SPE Kingdom of Saudi Arabia annual technical symposium and exhibition, Dammam, Saudi Arabia, 23-26 April. https://doi.org/10.2118/19223 9-MS

Al-Zubaidi N, Alwasiti A, Mahmood D (2017) A comparison of nano bentonite and some nano chemical additives to improve drilling fluid using local clay and commercial bentonites. Egypt J Pet 26(3):811-818. https://doi.org/10.1016/j.ejpe.2016.10.015

API (2004) Methylene blue test for drill solids and commercial bentonites. Section 12 in: API RP 13I: Laboratory Testing of Drilling Fluids, 7th edn, ISO 10416:2002. American Petroleum Institute, February

Balaban R, Vidal E, Borges M (2015) Design of experiments to evaluate clay swelling inhibition by different combinations of organic compounds and inorganic salts for application in water base drilling fluids. Appl Clay Sci 105-106:124-130. https:// doi.org/10.1016/j.clay.2014.12.029

Barry M, Jung Y, Lee J-K, Phuoc T, Minking K (2015) Fluid filtration and rheological properties of nanoparticle additive and intercalated clay hybrid bentonite drilling fluids. J Pet Sci Eng 127:338-346. https://doi.org/10.1016/j.petrol.2015.01.012

Beg M, Sharma S, Ojha U (2018) Effect of cationic copolyelectrolyte additives on drilling fluids for shales. J Pet Sci Eng 161:506514. https://doi.org/10.1016/j.petrol.2017.12.009

Carminati S, Del Gaudio L, Del Piero G, Brignoli M (2001) Waterbased muds and shale interactions. In: SPE international symposium on oilfield chemistry, Houston, Texas, 13-16 Feb. https ://doi.org/10.2118/65001-MS

Contreras O, Hareland G, Husein M, Nygaard R, Alsaba M (2014a) Experimental investigation on wellbore strengthening in shales by means of nanoparticle-based drilling fluids. In: SPE annual technical conference and exhibition, Amsterdam, The Netherlands. 27-29 Oct. https://doi.org/10.2118/170589-MS

Contreras O, Hareland G, Husein M, Nygaard R, Alsaba M (2014b) Wellbore strengthening in sandstones by means of nanoparticlebased drilling fluids. In: SPE deepwater drilling and completions conference, Galveston, TX, USA. 10-11 Sept. https://doi. org/10.2118/170263-MS

Ding Y, Zheng S, Meng X, Yang D (2018) Low salinity hot water injection with addition of nanoparticles for enhancing heavy oil recovery under reservoir conditions. In: SPE western regional meeting, Garden Grove, CA, USA. 22-26 April. https://doi. org/10.2118/190132-MS

Doleschall S, Milley G, Paal T (1987) Control of clays in fluid reservoirs. In: Proceedings volume, 4th BASF AG et al enhanced

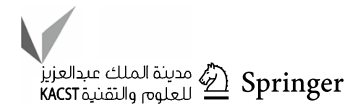


oil recovery Europe symposium. Hamburg, Germany, 27-29 Oct, pp 803-812

Elshawaf M (2018) Investigation of graphene oxide nanoparticles effect on heavy oil viscosity. In: SPE annual technical conference and exhibition, Dallas, TX, USA. 24-26 Sept. https://doi. org/10.2118/194037-STU

Fakoya M, Shah S (2018) Effect of silica nanoparticles on the rheological properties and filtration performance of surfactant-based and polymeric fracturing fluids and their blends. SPE Drill Complet 33(2):100-114. https://doi.org/10.2118/163921-PA

Horsrud P, Bostrom B, Sonstebo E, Holt R (1998) Interaction between shale and water-based drilling fluids: laboratory exposure tests give new insight into mechanisms and field consequences of $\mathrm{KCl}$ contents. In: SPE annual technical conference and exhibition, New Orleans, Louisiana. 27-30 Sept. https:// doi.org/10.2118/48986-MS

Hoxha B, Van Oort E, Daigle H (2017) How do nanoparticles stabilize shale? In: SPE international conference on oilfield chemistry, Montgomery, Texas, USA. 3-5 April. https://doi. org/10.2118/184574-MS

Kang Y, She J, Zhang H, You L, Minggu S (2016) Strengthening shale wellbore with silica nanoparticles drilling fluid. J Pet 2(2):189195. https://doi.org/10.1016/j.petlm.2016.03.005

Lal M (1999) Shale stability: drilling fluid interaction and shale strength. In: SPE Asia Pacific oil and gas conference and exhibition, Jakarta, Indonesia. 20-22 April. https://doi. org/10.2118/54356-MS

Minakov A, Zhigarev V, Mikhienkova E, Neverov A, Buryukin F, Guzei D (2018) The effect of nanoparticles additives in the drilling fluid on pressure loss and cutting transport efficiency in the vertical boreholes. J Pet Sci Eng 171:1149-1158. https://doi. org/10.1016/j.petrol.2018.08.032

Nwaoji C, Hareland G, Husein M, Nygaard R, Zakaria M (2013) Wellbore strengthening- nano-particle drilling fluid experimental design using hydraulic fracture apparatus. In: SPE/IADC drilling conference, Amsterdam, The Netherlands. 5-7 March. https://doi. org/10.2118/163434-MS

Parizad A, Shahbazi K, Abbas T (2018) Enhancement of polymeric water-based drilling fluid properties using nanoparticles. J Pet Sci Eng 170:813-828. https://doi.org/10.1016/j.petrol.2018.06.081

Perween S, Beg M, Shankar R, Sharma S, Amit R (2018) Effect of zinc titanate nanoparticles on rheological and filtration properties of water based drilling fluids. J Pet Sci Eng 170:844-857. https://doi. org/10.1016/j.petrol.2018.07.006

Ponmani S, Nagarajan R, Sangwai J (2016) Effect of nanofluids of $\mathrm{CuO}$ and $\mathrm{ZnO}$ in polyethylene glycol and polyvinylpyrrolidone on the thermal, electrical, and filtration-loss properties of water-based drilling fluids. SPE J 21(2):405-415. https://doi. org/10.2118/178919-PA

Pourkhalil H, Nakhaee A (2019) Effect of nano $\mathrm{ZnO}$ on wellbore stability in shale: an experimental investigation. J Pet Sci Eng 173:880-888. https://doi.org/10.1016/j.petrol.2018.10.064

Sensoy T, Chenevert M, Sharma M (2009) Minimizing water invasion in shales using nanoparticles. Presented at the SPE annual technical conference and exhibition, New Orleans, Louisiana. 4-7 Oct. SPE-124429-MS. https://doi.org/10.2118/124429-MS

Shi X, Wang L, Guo J, Su Q, Xiao Z (2018) Effects of inhibitor KCl on shale expansibility and mechanical properties. J Pet 225:5. https ://doi.org/10.1016/j.petlm.2018.12.005 (in press)

Singh R, Tong S, Panthi K, Mohanty K (2018) Nanoparticle-encapsulated acids for stimulation of calcite-rich shales. In: Unconventional resources technology conference. SPE/AAPG/SEG unconventional resources technology conference, Houston, TX, USA. USA, 23-25 July. https://doi.org/10.15530/URTEC-20182897114

Suresh R, Kuznetsov O, Agrawal D, Darugar Q, Khabashesku V (2018) Reduction of surfactant adsorption in porous media using silica nanoparticles. In: Offshore technology conference, Houston, TX, USA. 30 April-3 May. https://doi.org/10.4043/28879-MS

Van Oort E (2003) On the physical and chemical stability of shales. J Pet Sci Eng 38(3-4):213-235. https://doi.org/10.1016/s0920 $-4105(03) 00034-2$

Vipulanandan C, Mohammed A, Ganpatye A (2018) Smart cement performance enhancement with nano $\mathrm{Al}_{2} \mathrm{O}_{3}$ for real time monitoring applications using Vipulanandan models. In: Offshore technology conference, Houston, TX, USA. 30 April-3 May. https://doi. org/10.4043/28880-MS

Zargartalebi M, Barati N, Riyaz K (2014) Influences of hydrophilic and hydrophobic silica nanoparticles on anionic surfactant properties: interfacial and adsorption behaviors. J Pet Sci Eng 119:36-43. https://doi.org/10.1016/j.petrol.2014.04.010

Publisher's Note Springer Nature remains neutral with regard to jurisdictional claims in published maps and institutional affiliations. 